\title{
Zinc Finger Protein Gene Complexes on Mouse Chromosomes 8 and 11
}

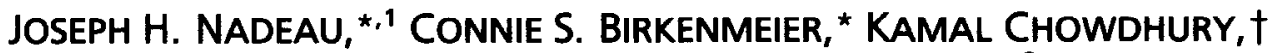 \\ JefFERY L. CROSBY, ${ }^{*} \ddagger$ AND PETER A. LALLEY $\S$ \\ *The Jackson Laboratory, Bar Harbor, Maine 04609; †Department of Molecular Cell Biology, Max Planck Institute of Biophysical \\ Chemistry, D-3400 Göttingen-Nikolausberg, West Germany; $¥ B$ Biochemistry Department, University of Maine, Orono, \\ Maine 04669; and §Center for Molecular Biology, Wayne State University, Detroit, Michigan 48202
}

Received April 27, 1989; revised June 14, 1990

Two murine homologs of the Drosophila Krüppel gene, a member of the gap class of developmental control genes that encode a protein with zinc fingers, were mapped to mouse chromosomes 8 and 11 by using somatic cell hybrids and an interspecific backcross. Surprisingly, both genes were closely linked to two previously mapped, Krüppelrelated zinc finger protein genes, suggesting that they are part of gene complexes. (c) 1990 Academic Press. Inc.

\section{INTRODUCTION}

DNA binding proteins can be classified into two groups on the basis of their binding motif. One group has the helix-turn-helix motif characteristic of procaryotic DNA binding proteins and eucaryotic proteins with the homeobox domain (Pabo and Sauer, 1984; Gehring and Hiromi, 1986; Colberg-Poley et al., 1987). The other group has a DNA binding domain known as a zinc finger. This binding motif is usually represented several times in the protein and is composed of two cysteine residues and one histidine residue that wrap around a zinc ion in a finger-like structure (Berg, 1988; Gibson et al., 1988).

One of the genes encoding a zinc finger protein is the Krüppel gene, which belongs to the gap class of developmental control genes in Drosophila (Preiss et al., 1985; Chowdhury et al., 1988). Zinc finger proteins are believed to regulate transcription of genes whose expression is essential during embryonic development (Ginsberg et al., 1984; Rosenberg et al., 1986; Kadonaga et al., 1987; Dressler and Gruss, 1988). Substitution of a single cysteine residue in the zinc binding domain of the Krüppel gene results in loss of wild-type function, i.e., lack of thoracic and five of

\footnotetext{
${ }^{1}$ To whom correspondence should be addressed.
}

eight abdominal segments and absence of malpighian tubules (Redemann et al., 1988).

Genes related to Krüppel have been described in the mouse (Schuh et al., 1986; Chowdhury et al., 1987; Chavrier et al., 1988; Dressler et al., 1988; Ashworth et $a l ., 1989)$ and three have been mapped, $Z f p-1$ to $\mathrm{Chr} 8$ (Chowdhury et al., 1989), $Z f p-3$ to $\mathrm{Chr} 11$, and $Z f p-4$ to Chr 8 (Ashworth et al., 1989). The chromosomal location of these genes may reveal candidate mutations that could be valuable in revealing the function of DNA binding proteins. Mapping one of the murine homologs of the Drosophila paired box family is an excellent example of this approach. Gene mapping showed that the Pax-1 gene was located near the undulated (un) mutation on mouse Chr 2 and suggested that Pax-1 and un may be the same (Deutsch et al., 1988). Sequence analysis of the Pax-1 gene in un/un and wild-type mice revealed a substitution that would result in an amino acid replacement in mutant mice (Balling et al., 1988). The un mutation may be invaluable for elucidating the function of this murine paired box gene. The present study was undertaken to map the second Krüppel-related gene, $Z f p-2$, reported by Chowdhury et al. (1987) and to determine the relative position of $Z f p-1$ and $Z f p-4$ on $\mathrm{Chr} 8$.

\section{MATERIALS AND METHODS}

Mice

Mice were obtained from the research and production colonies of The Jackson Laboratory.

\section{Somatic Cell Hybrids}

The panel of hybrids, which was formed by fusing Chinese hamster and BALB/cJ mouse spleen cells, has been described previously (Minna et al., 1975; Popp et al., 1981). 


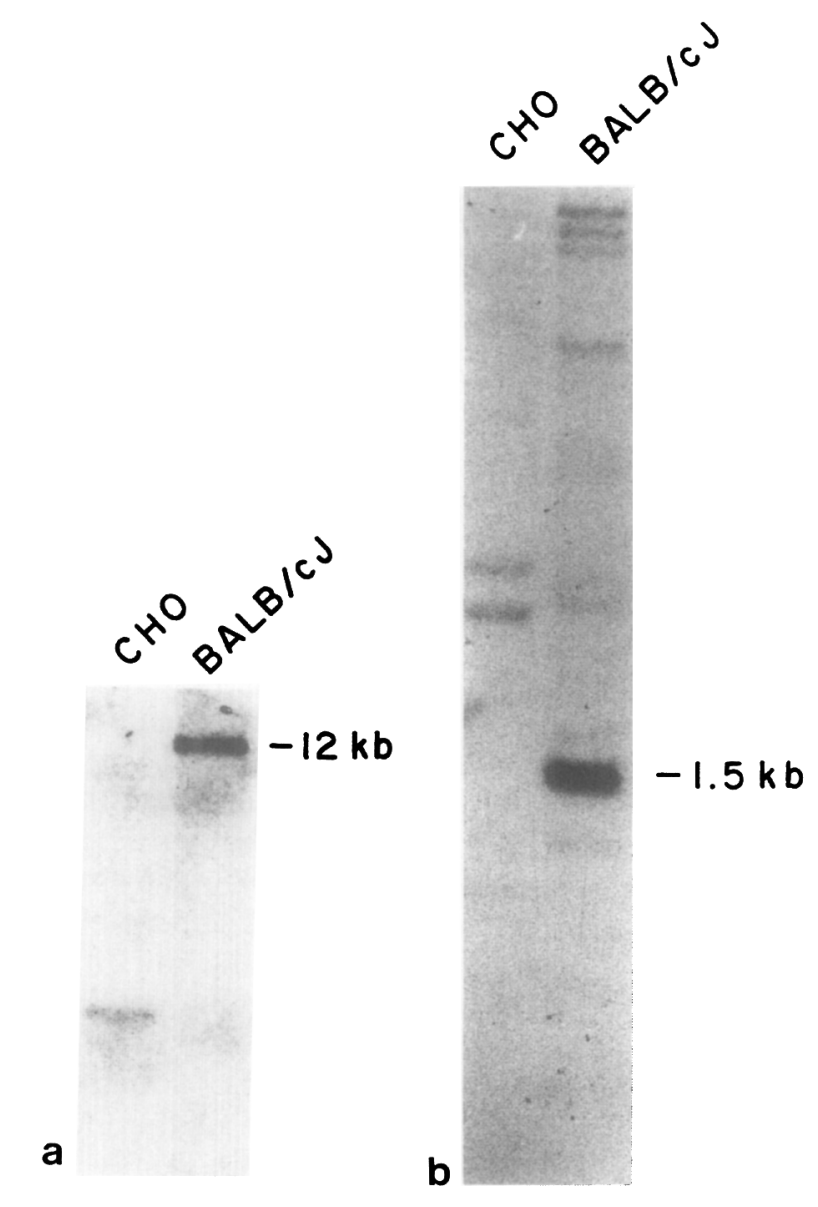

FIG. 1. Restriction fragments in a panel of mouse-Chinese hamster somatic cell hybrids. The size of the fragment used to analyze segregation is indicated. (a) $Z f p-2$ (Probe, pKC6; restriction cnzyme, StuI). The weakly hybridizing fragments observed in $\mathrm{BALB} / \mathrm{cJ}$ genomic DNA were not included in the segregation analysis because they could not be scored reliably. (b) $Z f p-1$ (Probe, pKC7; restriction enzyme, StuI).

\section{Isozyme Analysis}

ES-1 (esterase-1). Kidney samples were diluted with an equal volume of distilled $\mathrm{H}_{2} \mathrm{O}$, homogenized, and centrifuged for $5 \mathrm{~min}$ on a MC-150 microfuge with a TMA-S20 head (Tomy). Three microliters of supernatant was applied $1 \mathrm{~cm}$ from the cathodal end of a Titan III cellulose acetate plate (Helena Laboratories) with a Zip-Zone applicator (Helena Laboratories). The electrophoresis buffer consisted of $28 \mathrm{mM}$ $\mathrm{KH}_{2} \mathrm{PO}_{4}$ and $24 \mathrm{mMNa} \mathrm{Na}_{2} \mathrm{HPO}_{4}, \mathrm{pH}$ 6.8. Electrophoresis was conducted at $140 \mathrm{~V}$ for $30 \mathrm{~min}$ at room temperature. The stain consisted of $1 \mathrm{ml} 2 \% \alpha$-naphthyl acetate (in acetone) and $100 \mathrm{mg}$ Fast Blue RR in $10 \mathrm{ml}$ phosphate tray buffer. This stain was filtered, combined with $10 \mathrm{ml} 2 \%$ warmed agar, and used as an agar overlay. ES-1 is the most anodal zone of activity (Peters and Nash, 1977). The ES-1 isozyme in
C57BL/6J was more anodal than the ES-1 isozyme in Mus spretus.

GR-1 (glutathione reductase-1). Titan III cellulose acetate plates were soaked in a Tris-glycine buffer (0.025 $M$ Tris, $0.192 M$ ammonia-free glycine, $\mathrm{pH}$ 8.5) containing $8 \mathrm{mg}$ dithiothreitol per $150 \mathrm{ml}$ buffer. Three microliters of the kidney supernatant was then applied to the center of a cellulose acetate plate (Helena Laboratories) with a Zip-Zone applicator (Helena Laboratories). The Tris-glycine buffer was also used for electrophoresis, which was conducted at $200 \mathrm{~V}$ for $30 \mathrm{~min}$ at room temperature. The stain consisted of 7 $\mathrm{mg} \mathrm{NADPH}$ and $30 \mathrm{mg}$ oxidized glutathione in $10 \mathrm{ml}$ $0.3 M$ Tris- $\mathrm{HCl}$ buffer, $\mathrm{pH}$ 8.0. This mixture was combined with an equal volume of $2 \%$ warmed agar and used as an agar overlay. Enzymatic activity was visualized with uv light after incubating the gel for 30 min at $37^{\circ} \mathrm{C}$. GR-1 activity is found between the origin and the anodal end of the gel (Nichols and Ruddle, 1975). The GR-1A isozyme in C57BL/6J migrates more anodally than the GR-1 isozyme found in $M$. spretus.

\section{Genomic DNA}

DNAs were either purchased from the Mouse DNA Resource of The Jackson Laboratory or prepared from spleen and brain cells by using standard methods (Phillips and Nadeau, 1984).

\section{Krüppel Probes}

The $\lambda$ mkr1 and $\lambda$ mkr2 genomic clones were obtained by screening a mouse genomic library with a Krüppel cDNA containing most of the finger-encoding sequences (Chowdhury et al., 1987). The subclone pKC6 contains a 362-bp EcoRI fragment of $\lambda$ mkr2 inserted into the $E c o$ RI site in pTZ19R. The subclone pKC7 contains a 1045-bp PstI fragment from $\lambda$ mkr1 inserted into the PstI site of pSPT18 (Chowdhury and colleagues, unpublished data). The provisional names for genes represented within the insert of pKC6 and pKC7 were mKR2 and mKR1, respectively (Chowdhury et al., 1987). However, standard nomenclature following the recommendations of the Mouse Gene Nomenclature Committee was recently proposed (Chowdhury et al., 1989). The proposed symbols are Zfp-1 (pKC7, $\lambda$ mKR1) and Zfp-2 (pKC6, $\lambda$ mKR2) for zinc finger protein-1 and zinc finger protein-2, respectively.

To verify the authenticity of these probes, we tested insert size and presence of diagnostic restriction sites within the inserts. pKC6 was digested with $E c o R I$ and pKC7 with PstI. These digests released insert fragments whose sizes were approximately $350 \mathrm{bp}$ and 1 $\mathrm{kb}$, respectively. pKC6 has an RsaI site at bp 61 
TABLE 1

Segregation of pKC6 and pKC7 Restriction Fragments in a Panel of Mouse-Chinese Hamster Somatic Cell Hybrids ${ }^{a}$

\begin{tabular}{|c|c|c|c|c|c|c|c|c|c|c|c|c|c|c|c|c|c|c|c|c|c|c|}
\hline \multirow[b]{2}{*}{ Hybrid } & \multicolumn{20}{|c|}{ Mouse chromosome } & \multirow[b]{2}{*}{ pKC6 } & \multirow[b]{2}{*}{$\mathrm{pKC7}$} \\
\hline & 1 & 2 & 3 & 4 & $\mathbf{5}$ & 6 & 7 & 8 & 9 & 10 & 11 & 12 & 13 & 14 & 15 & 16 & 17 & 18 & 19 & $\mathbf{X}$ & & \\
\hline EBS-2 & - & - & + & - & + & + & - & - & + & - & - & + & + & + & + & + & - & $?$ & - & + & - & - \\
\hline EBS-3 & - & + & - & - & - & - & + & - & - & - & - & - & + & - & + & + & - & $?$ & - & + & - & - \\
\hline EBS-4 & - & - & - & - & - & - & - & - & - & - & - & - & + & - & + & - & + & - & - & + & - & - \\
\hline EBS-10 & + & - & + & - & - & - & + & - & - & + & - & + & + & - & + & - & - & - & - & + & - & - \\
\hline EBS-11 & - & $?$ & - & - & - & - & + & - & - & + & - & + & - & + & + & - & - & - & - & + & - & - \\
\hline EBS-13 & - & + & + & + & - & + & + & + & - & + & - & + & + & - & + & - & + & + & + & + & - & + \\
\hline EBS-15 & - & + & + & + & - & + & + & + & - & + & - & + & + & - & + & - & + & - & + & + & - & + \\
\hline EBS-17 & - & + & - & - & - & - & - & - & + & - & - & - & + & - & + & - & - & - & - & + & - & - \\
\hline EBS-18 & - & + & - & - & - & - & - & - & - & - & - & - & - & - & $F$ & - & - & - & - & + & - & - \\
\hline
\end{tabular}

${ }^{a}+$ indicates that the chromosome was present; -, absent; F, fragment; and ?, uncertainty, The criteria for characterizing the chromosomal constitution of hybrid cell lines are provided by Popp et al. (45).

within the 362-bp insert. A double digest of pKC6 with $E c o R I$ and $R s a \mathrm{I}$ produced the fragments of the expected size. pKC7 has a BamHI site at bp 418 and an EcoRI site at position 502 within the 1045-bp insert. Double digests of $\mathrm{pKC} 7$ with PstI and either $B a m \mathrm{HI}$ or EcoRI produced fragments of the expected sizes. These results confirmed the authenticity of these two probes.

Probes for $Z f p-3$ and $Z f p-4$ were described by Ashworth et al. (1989). A 4.9-kb XbaI fragment was used to follow inheritance of the $Z f p$-3 allele from $M$. spretus and an $8.2-\mathrm{kb} \mathrm{BglI}$ fragment to follow inheritance of the $Z f p-4$ allele from $M$. spretus.

\section{Trp53 Probe}

Probe 27.1a is a PstI-BglII fragment of the TRP53 cDNA (Jenkins et al., 1984). A 5.0-kb BglI restriction fragment was used to follow inheritance of the allele from $M$. spretus.

\section{Probes for Ankyrin-1 (Ank-1) and Plasminogen Activator, Tissue (Plat)}

These probes and restriction fragment variants in $M$. spretus were described by White et al. (1990).

\section{Mitochondrial Uncoupling Protein (Ucp)}

This probe was described by Jacobsson et al. (1985).

Southern Analysis, Probe Preparation, and Hybridization Conditions

The methods used were described in detail by Nadeau and Phillips (1987).

\section{Mutant Typing}

Rex $(R e)$ and trembler-J $\left(T r^{J}\right)$ are dominant mutations that were scored visually. Rex heterozygotes have curly whiskers and a wavy coat (Crew and Auerbach 1939). Trembler-J heterozygotes have rapid tremor beginning at 9 to 10 days of age, a tendency to convulsions, and spasticity in the muscles of the lower back and limbs (Falconer, 1951).

\section{Maximum Likelihood Analysis of Gene Order}

The program described by Nadeau et al. (1990) was used to identify the most likely gene order and to calculate the lod score for order for multilocus data (2 $<N<16$ ). This program is based on maximum likelihood methods described by Bishop (1985).

\section{RESULTS}

\section{Synteny of Mouse Krüppel Genes}

To establish synteny of $Z f p-2$ and to confirm synteny of $Z f p-1$, genomic DNAs from a panel of mouseChinese hamster somatic cell hybrids were typed by Southern blot analysis using pKC6 and separately $\mathrm{pKC} 7$ as hybridization probes. For $Z f p-2$, none of the hybrids had the 12-kb Stul fragment characteristic of BALB/cJ (Fig. 1a) and none of the hybrids had mouse Chr 11, suggesting that $Z f p-2$ is located on mouse $\mathrm{Chr}$ 11 (Table 1). This circumstantial evidence for synteny was confirmed through linkage analysis (see below). For $Z f p-1$, five of the hybrids had the 1.5-kb StuI 


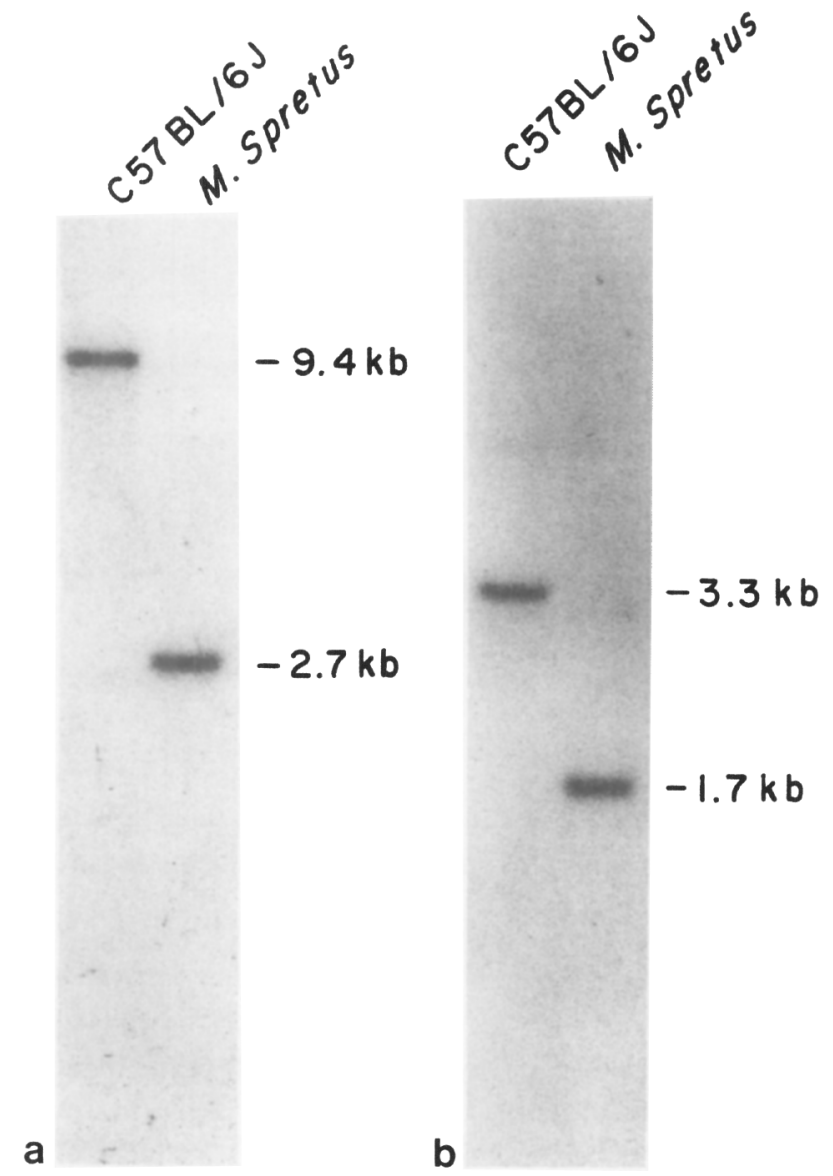

FIG. 2. Restriction fragments used in the segregation analysis of progeny of the backcross (C57BL/6J-TrJ Re/++) $\mathrm{F}_{1}$ females $\times$ C57BL/6J males. (a) Gene, Zfp-2; probe pKC6; restriction enzyme, StuI. (b) Gene, $Z f p-1$; probe, pKC7; restriction enzyme, PvulI.

fragment characteristic of BALB/cJ (Fig. 1b). There was complete concordancy between occurrence of this fragment among the hybrid lines and presence of mouse Chrs 4 and 8 (Table 1). This result is consistent with the previous linkage assignment of $Z \mathrm{fp}-1$ to Chr 8 (Chowdhury et al., 1989).

\section{Linkage and Gene Order}

To establish linkage of $Z f p-1$ and $Z f p-2$ to genetic markers on Chrs 8 and 11, respectively, progeny of an interspecific backcross (Robert et al., 1985; Guenet, 1986; Avner et al., 1988) were studied. Genomic DNAs from 44 backcross progeny of the backcross (C57BL/ 6J-TrJ $R e /++\times M$. spretus [Spain]) $F_{1}$ females $\times$ C57BL/6J males were digested with PvuII and Southern blots probed with pKC7 for $Z f p-1$. Segregation of the 1.7-kb PvuII restriction fragment characteristic of $M$. spretus was scored (Fig. 2b) and compared to the segregation patterns for six $\mathrm{Chr} 8$ markers Ank-1, Es-1, Gr-1, Plat, Ucp, and Zfp-4 (Ta- ble 2). The most likely gene order and recombination frequencies were Ank-1/Plat-0.045 $\pm 0.031-G r-1-$ $0.159 \pm 0.031-U c p-0.091 \pm 0.043-E s-1-0.023$ $\pm 0.023-Z f p-1 / Z f p-4$. An additional 12 backcross progeny, for a total of 60 progeny $(44+12=60)$, were typed for both $Z f p-1$ and $Z f p-4$. No crossovers were detected between $Z f p-1$ and $Z f p-4$, yielding an upper $95 \%$ confidence limit on the recombination frequency of 0.049 .

To verify evidence for synteny of $Z f p-2$ on Chr 11 and to establish linkage, genomic DNAs from 62 progeny of the backcross (C57BL/6J-Tr ${ }^{J} R e /++\times M$. spretus [Spain]) $F_{1}$ females $\times$ C57BL $/ 6 \mathrm{~J}$ males were digested with $S t u I$ and Southern blots were probed with pKC6 for Zfp-2. Segregation of the 2.7-kb StuI fragment characteristic of $M$. spretus was scored (Fig. 2a) and compared to the segregation pattern for Trp53, whose location on Chr 11 has recently been established (Buchberg et al., 1989), and to the previously published patterns for trembler $\left(T r^{J}\right)$, rex (Re), homeobox-2 (Hox-2), and keratin type I (Krt-1) (Table 3; Nadeau et al., 1989). Nineteen progeny were not typed for $T^{J}$.

An unexpectedly large number of apparent double crossovers were observed. Six of the 62 progeny appeared to have two crossovers between the flanking loci $T_{r}{ }^{J}$ and $H o x-2,4$ involved $Z f p-2$ alone, 1 involved Trp53 and $Z f p-3$, and 1 involved Trp53, Zfp-3, and Zfp-2 (Table 3 ). Although we originally suspected that typing errors were responsible for these six progeny, we were unable to identify the source of the error. These progeny were retyped for $Z f p-2, Z f p-3$, and Trp53, and results agreed with the original typing. Another explanation is that typing of $T^{J}$ was not entirely reliable because genetic background modified the trembler phenotype. Some backcross progeny were more severely affected on the hybrid C57BL/6J"spretus" backcross background than on the C57BL/ $6 \mathrm{~J}$ background (J. Nadeau and D. Varnum, unpublished data). If only affected progeny are considered, however, four apparent double crossovers remain. Thus, possible $\operatorname{Tr}^{J}$ mistyping does not fully account for the anomalous doubly recombinant progeny. Further work will be required to understand the origin of these anomalous progeny. These six progeny did not affect the inferred gene order, but clearly affected recombination frequencies. The most likely gene order and recombination frequencies were $\operatorname{Tr}^{J}-0.047$ $\pm 0.032-T r p 53-0.016 \pm 0.016-Z f p-3-0.081 \pm 0.035-$ Zfp-2-0.302 $\pm 0.058-H o x-2 / K r t-1 / R e$.

$Z f p-1$ provides a valuable marker for the central portion of Chr 8 in the CXB set of recombinant inbred strains. An $M s p I$ restriction fragment variant was used to map $Z f p-1$ in the CXB strains. The progenitors of these strains are BALB/cBy and C57BL/ 6By. The CXB-E, -G, and -I strains had the $3.5-\mathrm{kb}$ 
TABLE 2

Recombination between Ank-1, Es-1, Gr-1, Plat, Ucp, Zfp-1, and Zfp-4 in an Interspecific Linkage Cross between (C57BL/6J-Tr ${ }^{J} R /++\times$ Mus spretus[Spain])F $1 \times$ C57BL/6J

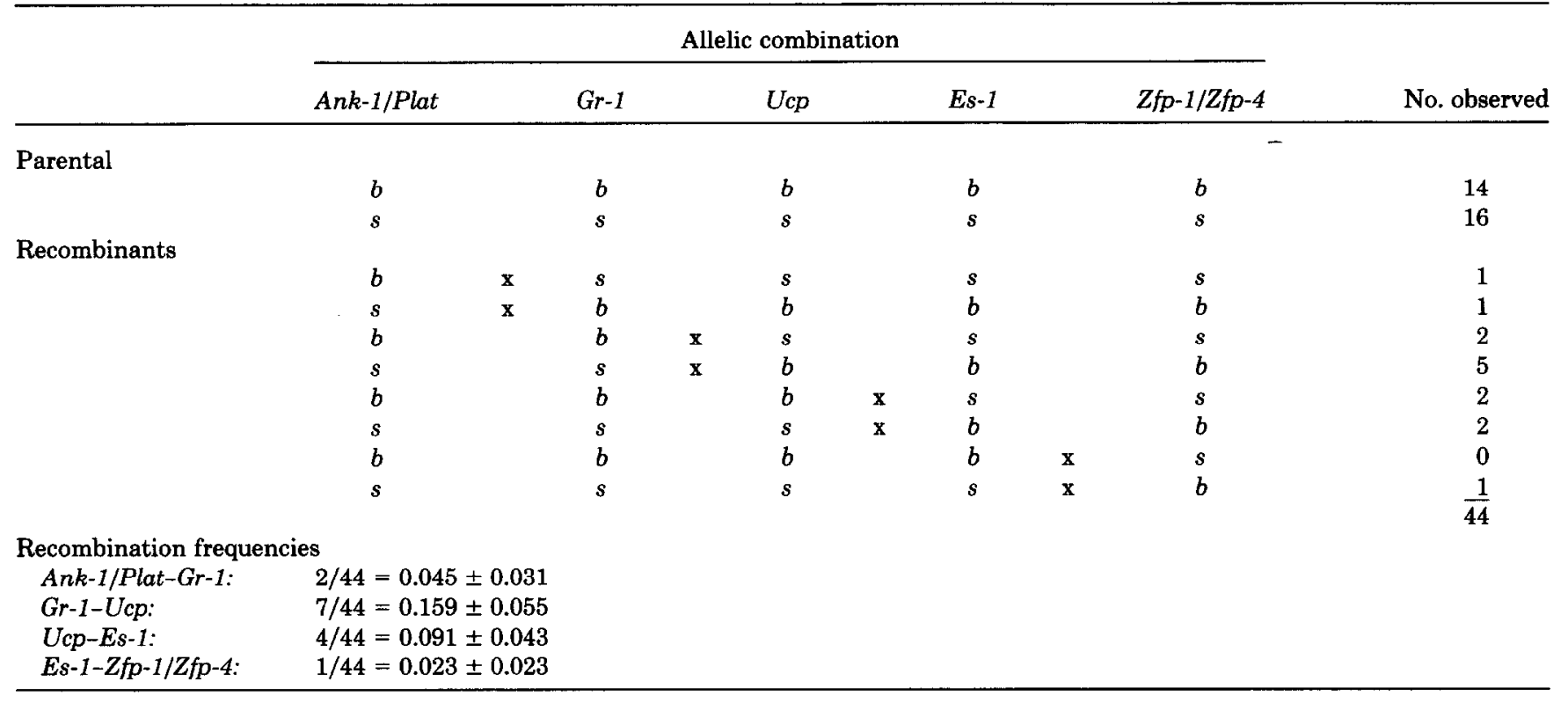

Note. An $\mathrm{x}$ indicates the position of a crossover. Lod score for order: 0.94 . The order given is more than eight times more likely than any other order. The next most likely order reverses the position of $Z f p-1 / Z f p-4$ and $E s-1$. The combined data of Chowdhury et al. (11) and the present study provide compelling evidence that $Z f p-1 / Z f p-4$ are distal to $E s-1$.

fragment characteristic of BALB/cBy, whereas the CXB-D, $-\mathrm{H}$, -J, and $-\mathrm{K}$ strains had the $6.0-\mathrm{kb}$ fragment characteristic of $\mathrm{C} 57 \mathrm{BL} / 6 \mathrm{~J}$.

\section{DISCUSSION}

One of the principal reasons for mapping genes such as $Z f p-1$ and $Z f p-2$ is to compare their chromosomal location with that of previously mapped genes to determine whether any existing mutations might involve these genes. Only two mutations, hydrocephalus-3 (hy-3) and scabby ( $s c b)$, are located near the likely location of $Z f p-1$ on $\mathrm{Chr} 8$, and three mutations, cocked (co), nude $(n u)$, and open eyelids (oe), are located near Zfp-2 on mouse Chr 11. In Drosophila, lack-of-function mutants fail to produce thoracic segments, most abdominal segments, and malpighian tubules (Wieschaus et al., 1984; Jäckle et al., 1985). On the basis of phenotypic effects, it is unlikely that any are candidates for mutations in either of these zinc finger protein genes.

Sequence and restriction fragment analysis demonstrates that the two Krüppel-related genes isolated by Ashworth et al. (1989) are distinct from those isolated by Chowdhury et al. (1989). Ashworth and colleagues (1989) isolated two Krüppel-related mouse cDNA clones by screening a $\lambda$ gt10 library of 8.5 -day postcoitum embryos and testis cDNA. DNA sequence analy- sis of these two clones showed that they were different from $Z f p-1$ and $Z f p-2$ (Ashworth et al., 1989; Chowdhury et al., 1989). Restriction fragment differences confirm that these are different genes. For example, comparison of $E c o R I$ digests of C57BL/6J genomic DNA typed with probes that were used to define $Z f p-2$ (present study, results not shown) and $Z f p-3$ (Ashworth et al., 1989) revealed fragments of different sizes. Similar differences were found in HindIII digests of C57BL/6J DNA typed with probes that were used to define $Z f p-1$ (present study, results not shown) and Zfp-4 (Ashworth et al., 1989).

The present study, together with those of Ashworth et al. (1989) and Chowdhury et al., (1989), provides evidence for two complexes of Krüppel-related zinc finger protein genes, one on Chr 8 between $U m$ and Tat (see Chowdhury et al., 1989, for evidence that $Z f p-1$ located between these two genes) and the other on Chr 11 between Trp53 and the Hox-2 and Krt-2 complexes. The absence of recombination (Table 2) clearly demonstrates that $Z f p-1$ and $Z f p-4$ define a gene complex.

The evidence for a $Z f p$ complex on Chr 11 is more ambiguous. The proximity of $Z f p-2$ and $Z f p-3$ is difficult to estimate because of the high frequency of apparent double crossovers. These crossovers are unusual because there are few if any precedents in the mouse. Buchberg et al. (1989) did not find anomalies 
TABLE 3

Recombination between $\operatorname{Tr}^{J}, Z f p-2, Z f p-3, T r p 53, H o x-2, K r t-1$, and Re in an Interspecific Linkage Cross between $\left(\mathrm{C57BL} / 6 \mathrm{~J}-\mathrm{Tr}^{J} \mathrm{Re} /++\times\right.$ Mus spretus $[$ Spain] $) \mathrm{F}_{1} \times \mathrm{C57BL} / 6 \mathrm{~J}$

\begin{tabular}{|c|c|c|c|c|c|c|c|c|c|c|}
\hline & \multicolumn{9}{|c|}{ Allelic combination } & \multirow[b]{2}{*}{ No. observed } \\
\hline & $\operatorname{Tr}^{d}$ & & $\operatorname{Trp53}$ & & $Z f p-3$ & & $Z f p-2$ & & $H o x-2 / K r t-1 / R e$ & \\
\hline \multicolumn{11}{|l|}{ Parental } \\
\hline & $\operatorname{Tr}^{J}$ & & $b$ & & $b$ & & $b$ & & $R e$ & 15 \\
\hline & $s$ & & $s$ & & $s$ & & $s$ & & $s$ & 15 \\
\hline \multicolumn{11}{|l|}{ Recombinants } \\
\hline & $\operatorname{Tr}^{J}$ & & $b$ & & $b$ & & $b$ & $\mathbf{x}$ & $s$ & 5 \\
\hline & $s$ & & $s$ & & $s$ & & $s$ & $\mathbf{x}$ & $R e$ & 3 \\
\hline & $\operatorname{Tr}^{J}$ & $\mathrm{x}$ & $s$ & & $s$ & $\mathrm{x}$ & $b$ & & $R e$ & 1 \\
\hline & $s$ & & $s$ & & $s$ & $\mathbf{x}$ & $b$ & $\mathbf{x}$ & $s$ & 1 \\
\hline & $\operatorname{Tr}^{J}$ & & $b$ & & $b$ & $\mathbf{x}$ & $s$ & $\mathbf{x}$ & $\operatorname{Re}$ & 2 \\
\hline & $s$ & $\mathrm{x}$ & $b$ & & $b$ & & $b$ & $\mathbf{x}$ & $s$ & $\frac{1}{43}$ \\
\hline & & & $b$ & & $b$ & & $b$ & & $R e$ & 4 \\
\hline & & & $s$ & & $s$ & & $s$ & & $s$ & 7 \\
\hline & & & $s$ & $\mathrm{x}$ & $b$ & & $b$ & & $\operatorname{Re}$ & 1 \\
\hline & & & $b$ & & $b$ & & $b$ & $\mathrm{x}$ & $s$ & 3 \\
\hline & & & $s$ & & $s$ & & $s$ & $\mathbf{x}$ & $R e$ & 3 \\
\hline & & & $s$ & & $s$ & $\mathbf{x}$ & $b$ & $\mathbf{x}$ & $s$ & $\frac{1}{19}$ \\
\hline \multicolumn{11}{|c|}{ Recombination frequencies } \\
\hline $\operatorname{Tr}-\operatorname{Trp53:}$ & \multicolumn{10}{|c|}{$2 / 43=0.047 \pm 0.032$} \\
\hline Trp53-Zfp-3: & \multicolumn{10}{|c|}{$1 / 62=0.016 \pm 0.016$} \\
\hline$Z f p-3-Z f p-2$ & \multicolumn{10}{|c|}{$5 / 62=0.081 \pm 0.035$} \\
\hline$Z f p-2-R e$ & \multicolumn{10}{|c|}{$19 / 63=0.302 \pm 0.058$} \\
\hline $\operatorname{Tr}-\operatorname{Re}$ & \multicolumn{10}{|c|}{$\begin{aligned} 13 / 43 & =0.302 \pm 0.070 \text { (including double crossovers) } \\
8 / 43 & =0.186 \pm 0.059 \text { (only single crossovers) }\end{aligned}$} \\
\hline
\end{tabular}

Nole. An $\mathrm{x}$ indicates the position of a crossover.

in their comparable interspecific linkage study of loci on mouse Chr 11. In fact, most interspecific crosses show a normal or reduced frequency of multiple crossovers (Mullins et al., 1988; Ceci et al., 1989; Mosely and Seldin, 1989; Siracusa et al., 1989; Crosby et al., 1990; Nadeau et al., 1990). The reason that Buchberg et al. (1989) failed to find this anomaly may be that the effect is very localized and that by chance they did not include a locus within this interval. Despite these crossovers, however, we hypothesize that these genes are physically close together as part of a gene complex and that a recombination anomaly is responsible for the double crossovers. Physical mapping of these complexes is under way (K. Willison, personal communication).

Genes involved in development have provided considerable evidence for duplicated chromosomal segments in the mouse genome. Perhaps the strongest example involves genes located on mouse Chrs 11 and 15. Small segments of each chromosome include a family of homeobox genes (Kappen et al., 1989; Schughart et al., 1989) and a family of keratin genes (Nadeau et al., 1989, and in preparation), and prelimi- nary evidence suggests retinoic acid receptor genes (J. Nadeau and colleagues, in preparation). Another excellent example involves the engrailed genes, $E n-1$ on Chr 1 and En-2 on Chr 5 (Martin et al., 1990). Moreover, as many as $30 \%$ of gene families whose members are located on more than one chromosome belong to duplicated segments (Nadeau, 1990). It is very likely therefore that $Z f p$ complexes on Chrs 8 and 11 mark duplicated chromosome segments.

These four genes belong to a large gene family that encode proteins with zinc fingers. In addition to $Z f p$ $1, Z f p-2, Z f p-3$, and $Z f p-4$, several zinc finger genes have been identified in mice, including ecotropic viral integration site-1 (Evi-1) on Chr 3 (Morishita et al., $1988)$, testis determining factor $(T d f)$ on the $\mathrm{Y}$ chromosome (Page et al., 1987), and the Krox gene family (Chavier et al., 1988). In man, at least five genes have been described: glioblastoma (GL1) on Chr 12q134q14.3 (Kinzler et al., 1988), early growth response gene-1 (EGR1) on Chr 5q23-31 (Sukhatme et al., 1988), zinc finger protein 3 (ZFP3) on Chr 17p12-17 (Ashworth et al., 1989), testis determining factor (TDF) on the Y chromosome (Page et al., 1987), and 
the candidate gene at the Wilms tumor locus (Call et al., 1990; Gessler et al., 1990). Gene mapping and structural analysis of each of these genes within and between species will provide considerable insight into the origin and evolution of this gene family.

\section{ACKNOWLEDGMENTS}

We thank Dr. Allan Bernstein for the gift of the Trp53 probe, Dr. Les Kozak for the Ucp probe, Carolyn Dunbar and Don Varnum for expert technical assistance, Dr. Eva Eicher for providing ES-1 and GR-1 electrophoretic methods and for providing the breeding stock of $M$. spretus, Michael Kosowsky for calculating the lod scores for order, Drs. Muriel Davisson and Mary Lyon for discussing nomenclature, and Drs. Muriel Davisson and Ben Taylor for helpful comments on a draft of this manuscript. This work was supported by NIH Grants HG00189 and HL29305.

\section{REFERENCES}

1. Ashworth, A., Williams, B. P., Buchberg, A. M., Goodfellow, P. N., Solomon, E., PotTer, J., AND Willison, K. R. (1989). Chromosomal localization of zinc finger protein genes in mouse and man. Genomics 4: 323-327.

2. Avner, P., Amar, L., Dandolo, L., AND Guenet, J.-L. (1988). Genetic analysis of the mouse using interspecific crosses. Trends Genet. 4: 18-23.

3. Balling, R., Deutsch, U., AND Gruss, P. (1988). Undulated, a mutation affecting the development of the mouse skeleton, has a point mutation in the paired box of Pax 1. Cell 55: 531-515.

4. BERG, J. M. (1988). Potential metal-binding domains in nucleic acid binding proteins. Science 232: 485486.

5. BISHop, D. T. (1985). The information content of phaseknown matings for ordering genetic information. Genet. Epidemiol. 2: 349-361.

6. Buchberg, A. M., Brownell, E., Nagata, S., Jenkins, N. A., AND Copeland, N. G. (1989). A comprehensive genetic map of murine chromosome 11 reveals extensive linkage conservation between mouse and man. Genetics 122: 153-161.

7. Call, K. M., Glaser, T., Ito, C. Y., Buckler, A. J., PelleTIER, J., Haber, D. A., Rose, E. A., Kral, A., Yeger, H., LEwIS, W. H., Jones, C., AND Housman, D. (1990). Isolation and characterization of a zinc finger polypeptide gene at the human chromosome 11 Wilms' tumor locus. Cell 60: 509-520.

8. Ceci, J. D., Siracusa, L. D., Jenkins, N. A., ANd Copeland, N. G. (1989). A molecular genetic linkage map of mouse chromosome 4 including localization of several proto-oncogenes. Genomics 5: 699-709.

9. Chavrier, P., Lemaire, P., Revelant, O., Bravo, R., and Charnay, P. (1988). Characterization of a mouse multigene family that encodes zinc finger structures. Mol. Cell. Biol. 8: 1319-1326.

10. Chowdhury, K., Deutsch, U., AND Gruss, P. (1987). A multigene family encoding several "finger" structures is present and differentially active in mammalian genomes. Cell 48: 771-778.

11. Chowdhury, K., Dietrich, S., Balling, R., Guenet, J.-L., AND Gruss, P. (1989). Structure, expression, and chromosomal localization of $Z f p-1$, a murine zinc finger protein gene. Nucleic Acids Res. 17: 10,427-10,438.

12. Chowdhury, K., RohDewohld, H., AND Gruss, P. (1988).
Specific and unbiquitous expression of different $\mathrm{Zn}$ finger protein genes in the mouse. Nucleic Acids Res. 16: 999510,011 .

13. Colberg-Poley, A. M., Voss, S. D., and Gruss, P. (1987). Homeo box genes of the mouse. Oxford Surv. Eucaryotic Genes 4: 92-115.

14. Crew, F. A. E., AND Augrbach, C. (1939). Rex: A dominant autosomal monogenic coat texture character in the mouse. $J$. Genet. 38: 455-457.

15. Crosby, J. L., Bleackley, R. C., ANd Nadeau, J. H. (1990). A complex or serine protease genes expressed preferentially in cytotoxic $\mathrm{T}$-lymphocytes is closely linked to the $\mathrm{T}$-cell receptor alpha and delta chain genes on mouse chromosome 14 . Genomics 6: 252-259.

16. Deutsch, U., Dressler, G. R., And Gruss, P. (1988). Pax 1, a member of a paired box homologous murine gene family, is expressed in segmented structures during development. Cell 53: $617-625$.

17. Dressler, G. R., Deutsch, U., Balling, R., Simon, D., GUENET, J.-L., AND GRUss, P. (1988). Murine genes with homology to Drosophila segmentation genes. Development (Suppl.) 104: 181-186.

18. Dressler, G. R., AND Gruss, P. (1988). Do multigene families regulate vertebrate development? Trends Genet. 4: 214219.

19. FaLCONER (1951). Two new mutants, "trembler" and "reeler," with neurological action in the house mouse (Mus musculus L.). J. Genet. 50: 192-201.

20. Gehring, W. J., AND Hiromi, Y. (1986). Homeotic genes and the homeo-box. Annu. Rev. Genet. 20: 147-173.

21. Gessler, M., Poutska, A., Cavenee, W., Neves, R. L., ORKIN, S. H., AND BRUNS, G. A. P. (1990). Homozygous deletion in Wilms tumors of a zinc-finger gene identified by chromosome jumping. Nature (London) 343: 774-778.

22. Gibson, T., Postma, J., Brown, R., ANd Argos, P. (1988). A model for the tertiary structure of the 28 residue DNA-binding motif (zinc finger) common to many eukaryotic transcription regulatory proteins. Protein Eng. 2: 209-218.

23. Ginsberg, A. M., King, B. O., AND Rokder, R. G. (1984). Xenopus 5S transcription factor, TFIIIA: Characteristics of a cDNA clone and measurement of RNA levels throughout development. Cell 39: 479-489.

24. GUENET, J.-L. (1986). The contribution of wild derived mouse inbred strains to gene mapping methodology. Curr. Top. Microbiol. Immunol. 127: 109-113.

25. Jäckle, H., Rosengerg, U. B., Preiss, A., Seifert, E., KNIPPle, D. C., Keilin, A., AND Lehman, R. (1985). Molecular analysis of Krüppel, a segmentation gene of Drosophila melanogaster. Cold Spring Harbor Symp. Quant. Biol. 50: 465473.

26. Jacobsson, A., Stadler, A., Glotzer, M. A., AND Kozak, L. P. (1985). Mitochondrial uncoupling protein from mouse brown fat: Molecular cloning, genetic maping and mRNA expression. J. Biol. Chem. 260: 16,250-16,254.

27. Jenkins, J. R., Rudge, K., ReDmond, S., AND Wade-Evans, A. (1984). Cloning and expression analysis of full length mouse cDNA sequences encoding the transformation associated protein p53. Nucleic Acids Res. 12: 5609-5626.

28. Kadonaga, J., Carner, K., Masiaz, F., And Tuian, R. (1987). Isolation of cDNA encoding transcription factor $\mathrm{Sp} 1$ and functional analysis of the DNA binding domain. Cell 51: 1079-1090.

29. Kappen, C., Schughart, K., and Ruddle, F. H. (1989). Two 
steps in the evolution of Antennapedia-class of vertebrate homeobox genes. Proc. Natl. Acad. Sci. USA 86: 5459-5463.

30. Kinzler, K. W., Rupper', J. M., Bigner, S. H., ANd VogelSTEIN, B. (1988). The GL1 gene is a member of the Krüppel family of zinc finger proteins. Nature (London) 332: 371-374.

31. Martin, G. R., Richman, S., Reinsch, S., Nadeau, J. H., AND JoYNER, A. (1990). Mapping of the two mouse engrailed-like genes: close linkage of $E n-1$ to dominant hemimelia $(D h)$ on chromosome 1 and of $E n-2$ to hemimelic extra-toes $(H x)$ on chromosome 6. Genomics 6: 309-315.

32. Minna, J. D., Marshall, T. H., ANd Shaffer-Berman, P. V. (1975). Chinese $\times$ mouse hybrid cells segregating mouse chromosomes and isozymes. Somatic Cell Genet. 1: 355-369.

33. Morishita, K., Parker, D. S., Mucenski, M. L., Jenkins, N. A., Copeland, N. G., aNd IhLe, J. N. (1988). Retroviral activation of a novel gene encoding a zinc finger protein in IL-3-dependent myeloid leukemia cell lines. Cell 54: 831-840.

34. Mosely, W. S., AND SELDIN, M. F. (1989). Detinition of chromosome 1 and 3 gene linkage groups that are conserved on human chromosome 1: Evidence that a conserved linkage group spans the centromere of human chromosome 1. Genomics 5: 187-194.

35. Mullins, L. J., Grant, S. G., Stephenson, D. A., AND ChapMAN, V. M. (1988). Multilocus molecular mapping of the mouse X chromosome. Genomics 3: 187-194.

36. NADEAU, J. H. (1990). Genome duplication and comparative gene mapping. In "Advanced Techniques in Chromosome Research" (K. Adolph, Ed.), Marcel Dekker, in press.

37. Nadeau, J. H., Berger, F. G., Cox, D. R., Crosby, J. L., Davisson, M. T., Ferrara, D., Fuchs, E., Hart, C., Hunihan, L., Lalley, P. A., Langley, S., Martin, G. R., Nichols, L., Phillips, S. J., Roderick, T. H., Roop, D. R., Ruddle, F. H., Skow, L. C., AND Compton, J. G. (1989). A family of type I keratin genes and the homeo box-2 gene complex are closely linked to the rex locus on mouse Chromosome 11. Genomics 5: 454-462.

38. Nadeau, J. H., Herrmann, B., Bucan, M., Burkart, D., Crosby, J. L., Erhart, M. A., Kosowsky, M., Kraus, J. P., Michiels, F., Schnattinger, A., Tchetgen, M.-B., VarNUM, D., Willison, K., Lehrach, H., and Barlow, D. (1990). Genetic maps of mouse chromosome 17 including 12 new anonymous DNA loci and 25 anchor loci. Submitted for publication.

39. Nadeau, J. H., and Phill.IPS, S. J. (1987). The putative oncogene Pim-1 in the mouse: Its linkage and variation among $t$ haplotypes. Genetics 117: 533-541.

40. Nichols, E. A., AND Ruddle, F. H. (1975). Polymorphism and linkage of glutathione reductase in Mus musculus. Biochem. Genet. 13: 323-329.

41. Pabo, C. O., ANd Sauer, R. T. (1984). Protein-DNA recognition. Annu. Kev. Biochem. 53: 293-321.

42. Page, D. C., Mosher, R., Simpson, E. M., Fisher, E. M. C., Mardon, G., Pollack, J., McGillivray, B., de la ChaPELle, A., AND BRown, L. G. (1987). The sex-determining region of the human $\mathrm{Y}$ chromosome encodes a finger protein. Cell 51: 1091-1104.
43. Peters, J., AND Nash, H. R. (1977). Polymorphism of esterase 1 in Mus musculus, a further esterase locus on chromosome 8. Biochem. Genet. 15: 111-114.

44. Phillips, S. J., And Nadeau, J. H. (1984). Personal communication. Mouse Newslett. 70: 83.

45. Popp, R. A., Lalley, P. A., Whitney, J. B., AND Anderson, W. F. (1981). Mouse alpha-globin genes and alpha-like pseudogenes are not syntenic. Proc. Natl. Acad. Sci. USA 78: 6362-6366.

16. Preiss, A., Rosenderg, U. B., Keinlin, A., Seifert, E., AND JÄCKLE, H. (1985). Molecular genetics of Krüppel, a gene required for segmentation of the Drosophila embryo. Nature (London) 313: 27-32.

47. RedemanN, N., Gaul, U., AND Jäckle, H. (1988). Disruption of a putative Cys-zinc interaction eliminates the biological activity of the Krüppel finger protein. Nature (London) 332: 90-92.

48. Robert, B., Barton, P., Minty, A., Daubas, P., Weydert, A., Bonhomme, F., Catalan, J., Simon, D., Guenet, J.-L., AND BUCKInGHAM, M. E. (1985). Investigation of genetic linkage between myosin and actin genes using an interspecific mouse backcross. Nature (London) 314: 181-183.

49. Rosenberg, U. B., Schröder, C., Preiss, A., Kielin, A., CoTE, S., RIEDE, E., AND JÄCKLE, H. (1986). Structural homology of the product of the Drosophila Krüppel gene with Xenopus transcription factor IIIA. Nature (London) 319: 336-339.

50. Schtuh, R., Aicher, W., Gati, U., Cote, S., Preiss, A., MaIER, D., Seifrert, E., Nauber, U., Schröder, C., Kemler, R., AND JÄCKLE, H. (1986). A conserved family of nuclear proteins containing structural elements of the finger protein encoded by Krüppel, a Drosophila segmentation gene. Cell 47: 1025-1032.

51. Schughart, K. C., Kappen, C., AND Ruddle, F. H. (1989). Duplication of large genomic regions during the evolution of vertebrate homeobox genes. Proc. Natl. Acad. Sci. USA 86: 7067-7071.

52. Siracusa, L. D., Buchrerg, A. M., Copeland, N. G., AND JENKINS, N. A. (1989). Recombinant inbred strain and interspecific backcross analysis of molecular markers flanking the murine agouti coat color locus. Genetics 122: 669-679.

53. Sukhatme, V. P., Cao, X., Chang, L. C., Tsai-Morris, C.-H., Stamenkovich, D., Ferriera, P. C. P., Cohen, D. R., Edwards, S. A., Shows, T. B., Curran, T., Lebeau, M. M., AND ADAMSON, E. D. (1988). A zinc finger-encoding gene coregulated with $\mathrm{c}$-fos during growth and differentiation and after cellular depolarization. Cell 53: 37-43.

54. White, R. A., Birkenmeier, C. S., Lux, S. E., AND Barker, J. E. (1990). Ankyrin and the hemolytic mutation, $n b$, map to mouse chromosome 8: Presence of the $n b$ allele is associated with a truncated erythrocyte ankyrin. Proc. Natl. Acad. Sci. USA 87: 3117-3121.

55. Wieschaus, E., Nüsslein-Volhard, C., and Kluding, $\mathbf{H}$. (1984). Krüppel, a gene whose activity is required early in the zygotic genome for normal embryonic segmentation. Dev. Biol. 104: 172-186. 